\title{
Review of the genus Maraenobiotus Mrázek, 1893 (Copepoda: Harpacticoida: Canthocamptidae) in Bulgaria with description of two new species
}

\author{
Apostol Apostolov \\ 1 Knyaz Alexander Batenberg Street, 8000 Burgas, Bulgaria, \\ apostolov2003@abv.bg; https://orcid.org/0000-0001-8712-9066 \\ http://zoobank.org/E4511E6E-7D81-49CB-A7D5-C5AE7B008F4C
}

\begin{abstract}
This article is devoted to a review of specimens identified as belonging to the genus Maraenobiotus Mrázek, 1893 reported for Bulgaria from the Rhodope and Rila Mountains under the name of Maraenobiotus vejdovskyi truncatus Gurney, 1932. Closer examination of the armature of the caudal rami and other morphological characteristics revealed significant differences between the specimens from these disjunctive populations and M. truncatus that had been originally described by Gurney (1932) from the United Kingdom. Based on these differences, the population from the Western Rhodope Mountains is described here as a new species, $M$. rhodopensis n. sp., and the population from the Rila Mountains is described here as $M$. rilaensis $\mathrm{n}$. sp.
\end{abstract}

Keywords: Bulgaria, copepods, freshwater, new species, taxonomy, water mosses

\section{Introduction}

The present study is a review of the material of the genus Maraenobiotus Mrázek, 1893 reported from the Rhodope and Rila Mountains (Bassamakov, 1969, 1973; Apostolov \& Pesce, 1989; Apostolov, 2010). Upon careful examination of the material, I found that the specimens belonging to two Bulgarian populations were two different new species. Although the specimens from the Rhodopes and Rila Mountains resemble the Maraenobiotus truncatus Gurney, 1932, they show different characteristics, suggesting the presence of two different species. The most important differences include the structure of the caudal rami, the ornamentation of the somites and the armature formula of the swimming legs.

Based on these differences, the population from the Rhodope Mountains is described here as a new

Received: 19 September 2020 • Editor: Nikolay Simov species. Similarly, the population from the Rila Mountains is described as another new species.

Additionally, new localities of $M$. bulbiseta Bassamakov \& Apostolov, 1989 in Bulgaria are given. The genus Maraenobiotus Mrázek, 1893 in
Bulgaria

The genus Maraenobiotus has not been the subject of special research in Bulgaria. Data on the diversity and distribution of Maraenobiotus from Bulgaria species can be found in few faunistic works on the harpacticoids from Bulgaria (Basamakov, 1969, 1973; Apostolov \& Pesce, 1989; Basamakov \& Apostolov, 1989). Based on these studies, six species of the genus Maraenobiotus have been reported from Bulgaria 
so far. However, this figure should not be considered as definitive since the harpacticoid fauna from a large part of the Bulgarian mountains remains unknown and is beyond the scope of the present study. Undoubtedly, future studies will reveal the presence of more species in all Bulgarian mountains. Such studies will not only contribute to the diversity and species composition of this genus in Bulgaria, but will be helpful also to clarify their systematic status and relationships. Species of this genus show variability in some morphological characteristics, which has been confirmed by the studied Bulgarian materials. Specimens from the Rhodope and Rila Mountains, previously attributed to $M$. truncatus, have been incorrectly identified. Bulgarian populations from the Rhodope and Rila Mountains belong to two new species of Mareanobiotus that differ in shape and size of the caudal rami and its main apical setae.

The distribution and habitat preferences of the species of Maraenobiotus known from Bulgaria are given below.

1. Maraenobiotus vejdovskyi vejdovskyi Mrázek, 1893

Maraenobiotus vejdovskyi: Sterba (1969: 257).

Maraenobiotus vejdovskyi vejdovskyi: Apostolov (2010: 180).

Distribution: Rila Mountains (Lake Elenino Ezero) and Vitosha Mountains (Dragalevtsi). The species has a Palaearctic distribution. It inhabits wet mosses, habitats near springs or marshes; the species is found in freshwater habitats and in caves.

2. Maraenobiotus brucei caucasicus Borutzky, 1934

Maraenobiotus brucei carpaticus: Bassamakov (1965: 11). Maraenobiotus brucei caucasicus: Bassamakov (1969: 80).

Distribution: Western Rhodope Mountains. The species was found in wet moss in a well at $1300 \mathrm{~m}$ a.s.l.

3. Maraenobiotus insignipes insignipes (Lilljeborg, 1902)

Maraenobiotus insignipes: Bassamakov (1970: 20). Maraenobiotus insignipes insignipes: Apostolov (2010: 186).

Distribution: Pirin Mountains. The species was found in moist mosses at an altitude of $2400 \mathrm{~m}$ a.s.l., near the summit of Vihren Peak. This species has a Palaearctic and Nearctic distribution.

\section{Maraenobiotus aischghoi (Schiklejev, 1931)}

Maraenobiotus insignipes f. aischghoi: Bassamakov (1970: 20).

Maraenobiotus aischghoi: Apostolov (2010: 189).

Distribution: Pirin and Rila Mountains. This species was found below the Hvoynati Peak in the Pirin Mountains at $2350 \mathrm{~m}$ a.s.l. and in the Rila Mountains in the area of Malyovitsa, Elenino Lake and Ochite area.

\section{Maraenobiotus bulbiseta Bassamakov \&} Apostolov, 1989

Maraenobiotus bulbiseta: Bassamakov \& Apostolov (1989: 97); Apostolov (2010: 191).

Distribution: Yagodinska Peshtera Cave in the Western Rhodopes, Stara Planina Mountains.

New localities: a small lake in the Kozarskata Cave and in the Temnata Dupka Cave in Karlukovo; in the Brounoshoushinska Cave, near the Gortalovo Village in the Pleven Region; in the Skoka Cave in the Dragana Village, Lovech Region, and in the Souhi pech Cave, near Oreshets Village in the Vidin Region).

\section{Maraenobiotus parainsignipes Apostolov, 1991}

Maraenobiotus parainsignipes: Apostolov (1991: 138); Apostolov (2010: 193).

Distribution: Ponor Mountains. This species was found inhabiting an underground stream in the Dushnika Cave (near the Iskrets Village).

\section{Material and methods}

In order to clarify the status of the materials of the genus Maraenobiotus Mrázek, 1893 reported for Bulgaria under the name of Maraenobiotus vejdovskyi truncatus Gurney, 1932 from the Rhodope and Rila Mountains, the published drawings and the established deviations from the diagnosis of the species by Basamakov $(1969,1973,1976)$ were used. Specimens from the author's personal collection from the Western Rhodope and Rila Mountains were analysed.

Habitat-specific samples collected by the author were taken using a fine mesh $(38 \mu \mathrm{m}), 15 \mathrm{~cm}$ in diam- 


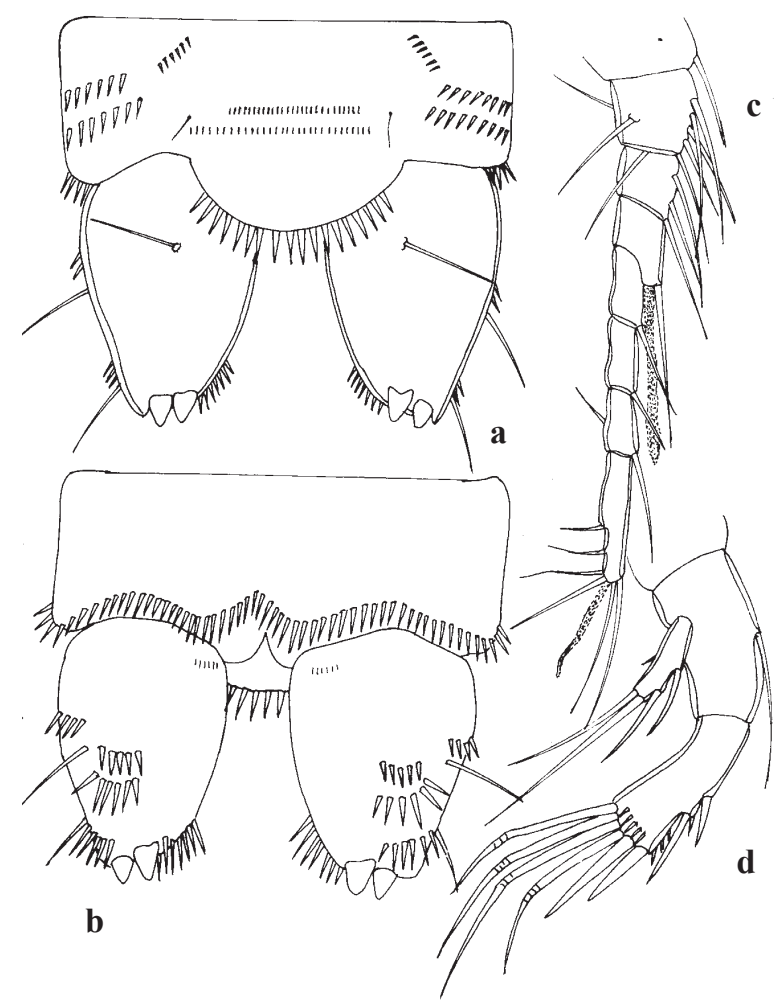

$\uparrow$ Fig. 1. Maraenobiotus rhodopensis n. sp. $q$ : (a) caudal rami, dorsal view; (b) caudal rami, ventral view; (c) antennule; (d) antenna.

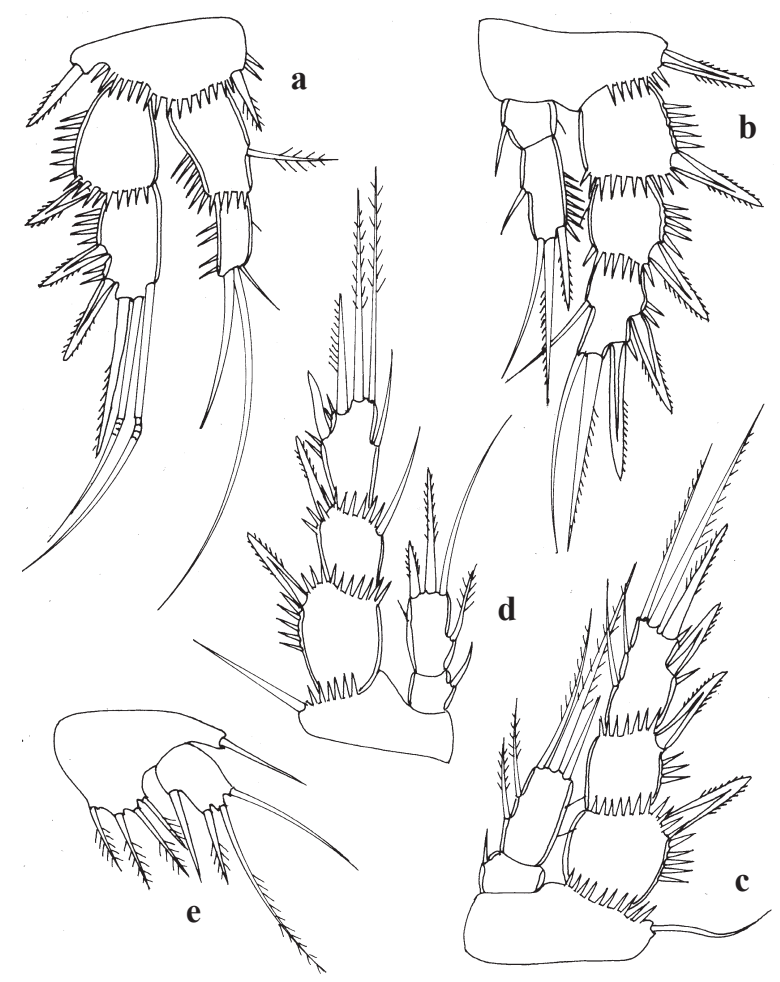

eter and $20 \mathrm{~cm}$ long. The collected material was fixed in $4 \%$ formalin and preserved in $70 \%$ ethanol for taxonomic analyses and descriptions. Observations and drawings were made based on whole and dissected specimens, using a microscope equipped with a drawing tube at a magnification of 400 and 1000 times.

The material described by Bassamakov (1969, 1973) from the Rhodope and Rila Mountains has been deposited in the Hydrobiology collection of the Natural History Museum in Plovdiv (NHMP). The material from the Western Rhodopes and the Rila Mountains described by Apostolov \& Pesce (1989) has been deposited in the author's personal specimen collection. Abbreviations used in the text and figures are: aesth - aesthetasc; exp - exopod; exp-1(-2-3), the first (second, third) segment of the exopod; enp - endopod; enp-1(-2-3), the first (second, third) segment of the endopod; $\mathrm{P}_{1}-\mathrm{P}_{6}$, swimming legs $1-6$.

\section{Systematics part}

Order Harpacticoida Sars G.O., 1903

Family Canthocamptidae Brady, 1880

Genus Maraenobiotus Mrázek, 1893

\section{Maraenobiotus rhodopensis $\mathbf{n} . \mathbf{s p}$.}

Maraenobiotus vejdovskyi f. truncatus Gurney, 1932: Bassamakov (1969: 82, figs 11-13).

Maraenobiotus vejdovskyi truncatus Gurney, 1932: Apostolov \& Pesce (1989: 126, fig. IV).

Material examined: holotype $ᄋ$ : Bulgaria, Western Rhodope Mountains, wet mosses, near the chalet 'Izgrev' at $1830 \mathrm{~m}$ a.s.1., water temperature $5^{\circ} \mathrm{C}$, 05.06.1968, leg. I. Bassamakov, deposited in the collection of the Natural History Museum in Plovdiv, Bulgaria; paratype $Q$ : Erkupriya (Chudnite Mostove), Western Rhodope Mountains at 1300 m a.s.l., June 10th 1975, leg. A. Apostolov, deposited in the author's personal collection.

Etymology: The name of the new species refers the region (Rhodope Mountains) where it was found. It is in the nominative singular. Gender masculine.

$\leftarrow$ Fig. 2. Maraenobiotus rhodopensis n. sp. + : (a) first thoracic leg; (b) second thoracic leg; (c) third thoracic leg; (d) fourth thoracic leg; (e) fifth thoracic leg. 


\section{Description}

Female (holotype). Body slender, length unknown. Without distinct demarcation between prosome and urosome; integument not strongly chitinised, colourless, without any naupliar eyes. Rostrum small, rounded, reaching proximal third of first antennullary segment. Cephalothorax wider than long, representing $21 \%$ of total body length, posterior edge without ornamentation, dorsally with several sensilla. Posterior margins of thoracic and abdominal somites smooth dorsally.

Genital double somite without ornamentation, with four sensilla. Fourth and fifth urosomites with several posterior spinules laterally. Anal somite with several rows of spinules dorsally (Fig. 1a), with a continuous row of strong spinules ventrally (Fig. 1b). Anal operculum (Fig. 1a) large, rounded, half the width of the anal somite, with 18 well-developed spinules along distal margin.

Caudal rami (Fig. 1a, b) 1.5 times as long as wide; distal inner corner with seven strong spinules; ventrally (Fig. 1b) - with two medial, one subdistal and one lateroventral row of spinules; with a short row of small spinules at the base of each furcal ramus. With five elements (without setae I and VI) as follows: lateral seta II displaced ventrally and originating midway from the outer margin; subdistal lateral seta III, slightly shorter than seta II; seta IV and V transformed into two blunt spines; dorsal seta VII originating medially, unarticulated.

Antennule (Fig. 1c) eight-segmented, unornamented, all setae smooth with one slender aesthetasc on fourth and eighth segments. Setal formula as follows: I - (1), II - (8), III - (3), IV - (1+aesth.), V - (1), VI - (1), VII - (2), VIII - (6+aesth.).

Antenna (Fig. 1d) with allobasis and one-segmented exopod and endopod. Allobasis unornamented, two times as long as wide, with one smooth abexopodal seta. Endopodal segment with two strong inner spines, apical armature consisting of two spines and four geniculate setae. Exopod 1 - segmented, short, laterally with two setae, apical armature consisting of two setae.

Mandible, maxillule, maxilla and maxilliped not observed, lost; the slide was in bad condition.

$\mathrm{P}_{1}$ with two-segmented exopod and endopod; $\mathrm{P}_{2}$ $\mathrm{P}_{4}$ with three-segmented exopods and two-segmented endopods (Fig. 2). Basis of $\mathrm{P}_{1}-\mathrm{P}_{4}$ ornamented with spinules as shown, of $\mathrm{P}_{1}-$ with bipinnate inner and outer spines, of $\mathrm{P}_{2}$ with outer bipinnate spines, of $\mathrm{P}_{3}$ and $\mathrm{P}_{4}$ - with outer smooth seta.

$\mathrm{P}_{1}$ (Fig. 2a) with two-segmented exopod and endopod; exopod-1 well developed, without inner seta, with one outer spine, with outer and distal spinules; exopod-2 with two strong outer bipinnate spines, one spiniform outer distal seta and two long geniculate setae placed distally. Endopod two-segmented, slightly shorter than exopod; first segment 1.5 times as long as wide, with plumose inner seta and with outer spinules; second segment short, with few small outer spinules, distally with three elements, of which innermost shortest and bare, middle seta longest and geniculate, outer element spiniform.

$\mathrm{P}_{2}$ (Fig. 2b) with three-segmented exopod; first segment well developed; first and second segments without inner seta; third segment with smooth inner seta, and two outer bipinnate spines, distally with two long setae of which inner apical seta thin, long and smooth, outer apical seta robust, spiniform; with one inner seta. Endopod two-segmented, reaching the middle of exopod-2; first segment shorter than second, with one inner short seta; second segment ornamented with spinules along outer margin, twice as long as wide, with inner short seta and two apical setae and one outer bipinnate spine.

$\mathrm{P}_{3}$ (Fig. 2c): exopod as in $\mathrm{P} 2$ except for third segment, which with two inner short, smooth setae. Endopod two-segmented, reaching the middle of the second exopodal segment; endopod-1 small, wider than long, with small inner seta; endopod-2 two times as long as wide, with two plumose inner setae, two short apical outer spines and two apical setae.

$\mathrm{P}_{4}$ (Fig. 2d) with three-segmented exopod, each segment with one row of outer spinules as shown; first segment without inner armature, with outer bipinnate spine; second segment with one inner seta and outer bipinnate spines; third segment with one smooth inner seta, two long bipinnate distal setae, robust spiniform outer terminal element and one outer spine. Endopod two-segmented, reaching tip of exopod-1, armed as in $\mathrm{P}_{2}$ except for bipinnate inner seta on $\mathrm{P}_{4}$ endopod-2.

Armature formula of female $\mathrm{P}_{2}-\mathrm{P}_{4}$ as follows: Exopodite Endopodite

$\begin{array}{llllll}\mathrm{P}_{2} & 0 & 0 & 122 & 1 & 121 \\ \mathrm{P}_{3} & 00 & 222 & 1 & 221 \\ \mathrm{P}_{4} & 01 & 122 & 1 & 121\end{array}$

$\mathrm{P}_{5}$ (Fig. 2e): both legs separated. Exopod and baseoendopod not fused. Baseoendopod with smooth outer basal seta, unornamented; endopodal lobe with 
four strong pinnate spines of unequal lengths. Exopod ovate, 1.5 times as long as wide, unornamented, with one smooth inner seta and three apical setae of unequal lengths (innermost shortest and bipinnate, medial longest and unipinnate, outermost thin and naked).

Male. Unknown.

Variability. Not observed.

Distribution. At present, Maraenobiotus rhodopensis n. sp. is known only from two closely-situated localities in the Western Rhodope Mountains, Bulgaria.

Discussion. Maraenobiotus rhodopensis n. $\mathrm{sp}$. is similar to the species $M$. vejdovskyi and M. truncatus in the armature formula of the thoracic legs. However, the new species is easily distinguished from the other two species by the ornamentation of the urosomites and by the shape of the caudal rami. The anal operculum of $M$. rhodopensis n. sp. has 18 strong spinules, while only eight spinules are present in the anal operculum of $M$. vejdovskyi and the anal operculum of $M$. truncatus has hairs on the posterior edge. The new species has a very characteristic shape and length of the caudal rami and conformation of the furcal setae, which is ornamented with seven strong subdistal inner spinules and with several spinular rows close to the well-developed lateral setae II and III, while caudal setae IV and V are modified into two blunt short spines. Setae IV and V are normal in $M$. vejdovskyi with seta IV being bulbous at its base; seta VI is missing in the new species and according to Thiébaud (1936) "c'est un fait assez général que, chez les Harpacticides muscicoles, les modifications adaptatives par réduction des soies furcales se constatent surtout chez la femelle, tandis que le mâle est plus réfractaire et conserve les caractères primitifs" (M. truncatus, M. slovenicus, $M$. ishidai, M. pescei, M. galassiae). Maraenobiotus rhodopensis n. sp., differs from M. truncatus in the shape and length of the caudal rami, 1.5 times longer than wide, in $M$. truncatus square and the number of setae on the $\mathrm{P}_{5}$ exopod (four instead of three).

\section{Maraenobiotus rilaensis $\mathbf{n}$. sp.}

Maraenobiotus vejdovskyi truncatus (Richard): Bassamakov (1973: 59, figs 4-5); Apostolov (2010: 185, fig. 60).

Material examined: holotype o: $_{\text {B }}$ Bulgaria, Rila Mountains, summit of Malyovitsa at 2729 m a.s.l., 18.06.1970, leg. I. Bassamakov, in the collection of

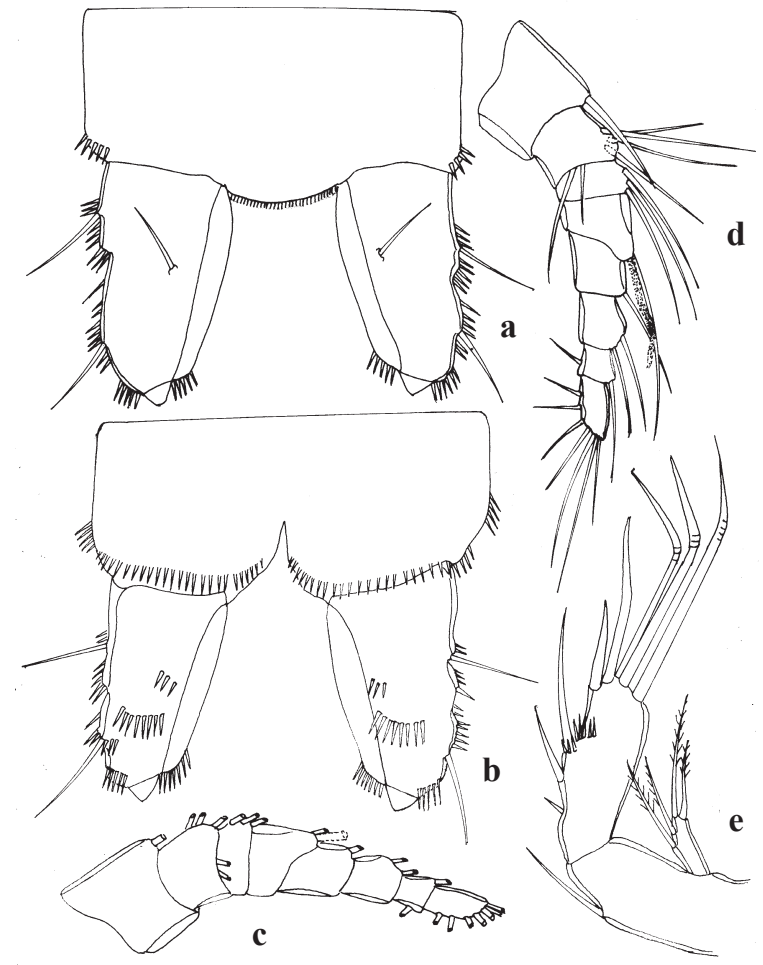

Fig. 3. Maraenobiotus rilaensis n. sp. ㅇ: (a) caudal rami, dorsal view; (b) caudal rami, ventral view; (c - d) antennule; (e) antenna.

the Natural History Museum in Plovdiv, Bulgaria; paratypes 2 우: Bulgaria, Rila Mountains, summit of Malyovitsa, 20.08.1970, leg. A. Apostolov; deposited in the author's personal collection.

Etymology: The name of the new species refers the region (Rila Mountains) where it was found. It is in the nominative singular. Gender masculine.

\section{Description}

Female. Body compact, cylindrical; last three urosomites slightly narrower than preceding somites; colour of preserved specimen yellowish; nauplius eye absent. Total body length $0.64 \mathrm{~mm}$. Rostrum reaching middle of second antennular segment, ornamented with two sensilla dorso-laterally. Cephalothorax wider than long, $21.4 \%$ of total body length with sensilla as shown. Prosome longer than urosome; the latter composed of $\mathrm{P}_{5}$-bearing somite, genital double somite and three free abdominal somites; urosomites without spinular ornamentation. 

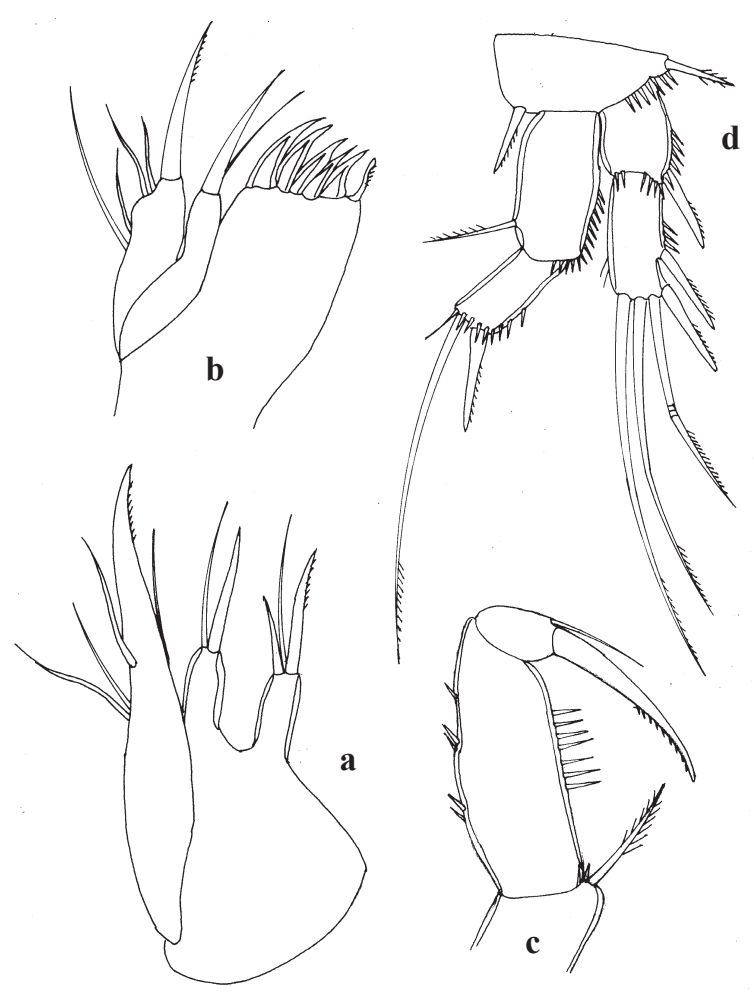

Fig. 4. Maraenobiotus rilaensis n. sp. $q$ : (a) maxilla; (b) maxillule; (c) maxilliped; (d) first thoracic leg.

Genital double somite two times as wide as long in dorsal view, ornamented with five dorsal sensilla. Fifth pedigerous somite (first urosomite) with four dorsal and two lateral sensilla (one on each side). Ventrally, surface of posterior half of genital double somite with discontinuous and of fourth somite with continuous row of spinules. Anal somite wider than long, with lateral and ventral spinules above each caudal ramus and dorsally with two sensilla.

Anal operculum (Fig. 3a) $31.25 \%$ of anal somite width, with hairs on posterior margin.

Caudal rami (Fig. 3a, b) very long, cylindrical, parallel, with gap between them, about ramus width, 1.75 times as long as wide, ornamented with seven large spinules distally, along the inner margin and five large spinules distally, along the outer margin, with short rows of spinules laterally, along the caudal margin; ventrally with two rows of large spinules. With three armature elements. Seta II about 0.5 times as long as dorsal seta VII, smooth; seta III as long as seta II; dorsal seta VII relatively short and smooth; distal principal setae transformed into a blunt spine.

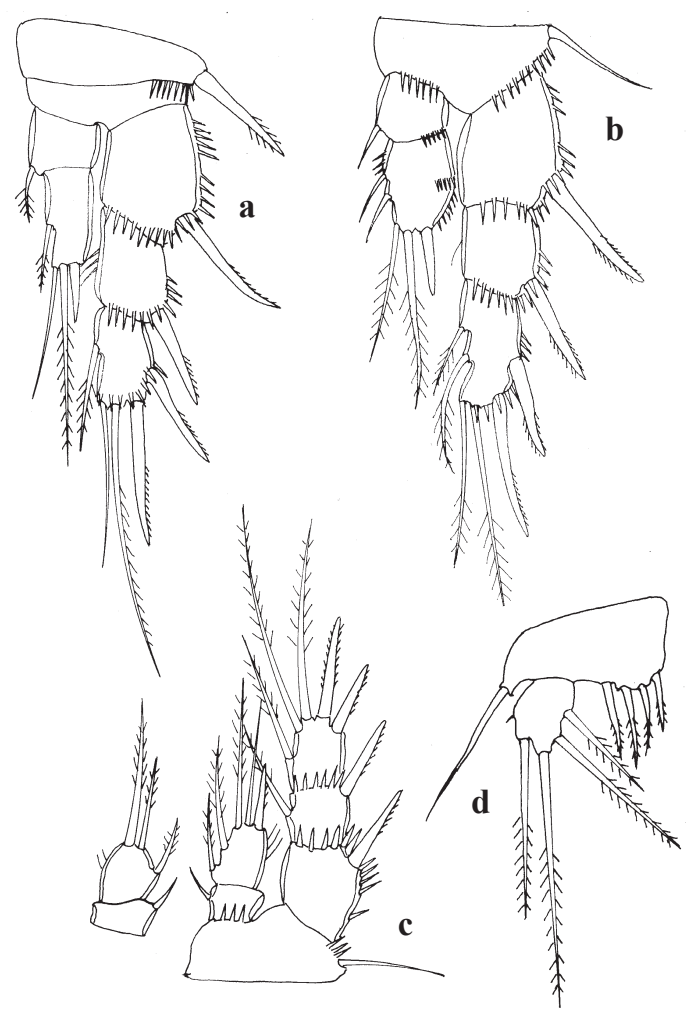

Fig. 5. Maraenobiotus rilaensis n. sp. $q$ : (a) second thoracic leg; (b) third thoracic leg; (c) fourth thoracic leg; (d) fifth thoracic leg.

Antennule (Figs. 3c, d) eight-segmented, shorter than cephalothorax, unornamented; all setae smooth, with aesthetasc on fourth segment, reaching the middle of the seventh segment. Length ratio of antennular segments, from proximal to distal segment: $1: 1: 0.5$ $: 1: 0.9: 0.7: 0.5: 0.9$. Setal formula as follows: I1, II - 6, III - 3, IV - 1+aesth., V - 1, VI - 2, VII - 2, VIII -7 .

Antenna (Fig. 3e) with allobasis and one-segmented exopod and endopod. Allobasis about twice as long as wide, with long smooth abexopodal seta. Free endopodal segment with two strong spines on outer margin and several spinules at the base of the second spine; apical armature consisting of two spines, of which outermost twice as long as innermost spine, and three geniculate setae. Exopod one-segmented, with four spiniform setae (two internal and two apical).

Maxillule (Fig. 4b): coxal endite cylindrical, four times as long as wide, with one strong spine and one thin smooth seta. Basis with one strong and long unipinnate spine. Exopod and endopod reduced, fused to basis, represented by two smooth setae each. 
Maxilla (Fig. 4a) with two endites on syncoxa: proximal endite cylindrical, twice as long as wide, with one smooth seta, one unipinnate spine and one short smooth spiniform seta; distal endite cylindrical, longer than the proximal endite, armed apically with one long smooth setae and one stronger and long spine. Allobasis with long claw and two setae at base. Endopod represented by two smooth setae.

Maxilliped (Fig. 4c) composed of syncoxa, basis and one-segmented endopod. Syncoxa unornamented, with one plumose seta near distal edge. Basis three times as long as wide, with one row of seven inner medial spinules and few smaller spinules along outer margin as shown. Endopod with one very long curved unipinnate claw, accompanied at base by one thin smooth seta.

$\mathrm{P}_{1}$ (Fig. 4d) with two-segmented exopod and endopod, the latter longer. Basis with robust internal spiniform seta with spinules on outer margin and with outer spine. Exopod-1 shorter than exopod-2, with strong outer spine and with spinules along outer margin; exopod-2 two times as long as wide, with two strong outer spines and one geniculate seta terminally. Endopod-1 1.8 times as long as wide, reaching slightly above the middle of exopod-2, with one long inner seta, with spinules along outer margin; endopod-2 two times as long as wide, terminally with three setae, inner distal seta - short and thin, medial - long, outer - a unipinnate spine.

$\mathrm{P}_{2}$ (Fig. 5a): basis with outer spine, with strong spinules at base of exopod. Exopod three-segmented: first segment well-developed; first and second segments without inner setae; third segment with plumose inner seta, two outer unipinnate spines, one short and thin apical inner smooth seta and one long thin apical medial unipinnate element. Endopod two-segmented, reaching the middle of exopod-2; first segment with inner plumose short seta; second segment twice as long as wide, with one inner seta, one apical outer spine, one apical medial plumose seta and one apical inner short smooth seta.

$\mathrm{P}_{3}$ (Fig. 5b): basis with long and thin outer seta. Exopod three-segmented, each segment with row of spinules along outer margins; first and second segment as in $\mathrm{P}_{2}$, third segment about twice as long as wide, with two strong outer spines, two inner plumose setae and two apical plumose elements of different lengths. Endopod two-segmented, endopod-1 with one small inner smooth seta; second segment with a proximal row of spinules on outer margin, with two inner small bare setae, two long plumose setae and one spine distally.

$\mathrm{P}_{4}$ (Fig. 5c): basis with long and thin outer seta. Exopod three-segmented; exopod-1 with one outer unipinnate spine, without inner seta; exopod-2 with one outer spine and with plumose inner seta; exopod-3 with one inner plumose seta, two apical plumose elements and two pinnate spines. Endopod three-segmented; endopod-1 as wide as long, smaller than in $\mathrm{P}_{3}$ with one small inner seta; endopod-2, 1.5 times as long as wide, with two plumose inner setae and two plumose setae and one spine apically.

Armature formula of female $\mathrm{P}_{2}-\mathrm{P}_{4}$ as follows:

\begin{tabular}{llll}
\multicolumn{2}{l}{ Exopodite } & \multicolumn{2}{l}{ Endopodite } \\
00 & 122 & 1 & 121 \\
00 & 222 & 1 & 221 \\
01 & 221 & 1 & 221
\end{tabular}

$\mathrm{P}_{5}^{4}$ (Fig. 5d): both legs separated. Exopod and baseoendopod not fused. Baseoendopod wider than long, with short outer setophore bearing basal seta; endopodal lobe with four strong pinnate spines of unequal length. Exopod 1.2 times as long as wide, with four plumose setae of which two plumose inner setae of unequal length, distal seta very long and plumose and outer plumose seta shorter.

Male: Unknown.

Variability (Fig. 5c): The second endopodal segment of the female left $\mathrm{P}_{4}$ has five setae; the same article on the right leg is armed with three setae.

Distribution. At present, Maraenobiotus rilaensis n. sp. is known from a single locality in the Rila Mountains at $2729 \mathrm{~m}$ a.s.l. among wet mosses.

Discussion. Maraenobiotus rilaensis n. sp. has very strong affinities with $M$. vejdovskyi and $M$. truncatus. The armature complement of $\mathrm{P}_{1}-\mathrm{P}_{3}$ and exopod of $\mathrm{P}_{4}$ are identical to that of $M$. vejdovskyi. On the other hand, the new species shares the swimming leg armature formula of $\mathrm{P}_{1}-\mathrm{P}_{2}$ and of the exopod of $\mathrm{P}_{4}$ with $M$. truncatus. However, there is a significant difference between these two species. Maraenobiotus rilaensis $\mathrm{n}$. $\mathrm{sp}$. differs in the armature formula of the second endopodal segment of the female $\mathrm{P}_{4}$ (with two inner setae in the new species but one in $M$. vejdovskyi and M. truncatus); in the armature complement of the exopod of $\mathrm{P}_{5}$ (with four or five setae in M. rilaensis $\mathrm{n}$. sp. but three in $M$. truncatus). The most evident difference lies in the length, shape and ornamentation of the caudal rami in $M$. rilaensis $\mathrm{n}$. sp. (1.75 times as long as wide; ornamented with a seven spinules distally, along the inner margin and five large spinules distally, 
along the outer margin; with short rows of spinules laterally along caudal margin; ventrally with two rows of large spinules. In $M$. truncatus the caudal rami are square with one row of spines from the inner distal part), as well as in the reduction of the apical setae of the caudal rami into blunt spine in M. rilaensis $\mathrm{n}$. $\mathrm{sp}$.

\section{Acknowledgements}

My sincere thanks to Dr Samuel Gómez of the Instituto de Ciencias del Mar y Limnología, Unidad Académica Mazatlán, Universidad Nacional Autónoma de México, Mazatlán, México, for his comments on the first draft of the manuscript. I take the opportunity to express my sincere gratitude to Dr Vesela Evtimova of the Institute of Biodiversity and Ecosystem Research, Bulgarian Academy of Sciences, Sofia, who corrected the English language.

\section{References}

Apostolov A. 1991 Maraenobiotus parainsignipes sp. n. (Copepoda, Harpacticoida) from a cave in Bulgaria. Zoologicheskii Zhurnal 70 (2): 138-142. (In Russian)

Apostolov A. 2010 Copepoda, Harpacticoida (Freshwater harpaticoids). Fauna Bulgarica 29: 1-347. (In Bulgarian)

Apostolov A., Pesce L. 1989 Copépodes Harpacticoides stygobies de Bulgarie. Rivista Idrobiologia 28 (1-2): 113-149.
Bassamakov I. 1965 Matériaux sur Harpacticoida en Bulgarie. Bulletin of the museums Plovdiv 4: 9-10.

Bassamakov I. 1969 Aport versl'étude d'Harpacticoida (Crustscea, Copepoda) de la montagne de Rhodopa en Bulgarie. Fragmenta balcanica 7 (10): 77-85.

Bassamakov I. 1970 Contribution to the study of harpacticoida (Crustacea, Copepoda) from Pirin Mountain. Magazine Museums and Monuments of Culture 1: 17-20. (In Bulgarian)

Bassamakov I. 1973 Harpacticoida from the NorthWest mountain range of Rila. Bulletin of the museums of South Bulgaria 2: 55-64. (In Bulgarian)

Bassamakov I. 1976 Harpacticoida (Crustacea, Copepoda) from the Rhodope in Bulgaria. Bulletin of the museums of South Bulgaria 2: 65-74. (In Bulgarian)

Bassamakov I., Apostolov A. 1989 Maraenobiotus bulbiseta $\mathrm{n}$. sp. nouvel copépod harpacticoide cavernicole de la montagne Rhodopie (Sud Bulgarie). Bulletin of the museums of South Bulgaria 15: 97-103.

Gurney R. 1932 British freshwater Copepoda: Harpacticoida. The Ray Society, London, 336 pp.

Šterba O. 1969Zur Kenntnis der Gattung Hypocamptus Chappuis, 1929 (Copepoda: Harpacticoida). Vestník Ceskoslovenské spolecnosti zoologické 33: 257-264.

Thiébaud M. 1936 Harpacticoides muscicoles des Alpes et du Jura. Bulletin Société Neuchateloise science nature 61: 183-204. 